Researches on Crustacea, No. 15

Carcinological Society of Japan

Odawara Carcinological Museum

Azabu-Juban 3-11, Minatoku, Tokyo

(Issued-April 30, 1986)

\title{
ZOEAL DEVELOPMENT OF THE SWIMMING CRAB, THALAMITA PRYMNA (HERBST); PORTUNIDAE, PORTUNINAE
}

With 1 Text-figure

By

Masayuki TERADA

(Yokosuka High School, Ōsuka-cho, Shizuoka-ken 437-13, Japan)

ペニツケガニのゾェア幼生

插図 1

寺田正之

（静岡県立横須賀高等学校）

\begin{abstract}
Larvae of the swimming crab, Thalamita prymna (Herbst), were successfully reared in the laboratory from hatching to the last zoeal stage. They were fed on Artemia salina (L.) nauplii. These zoeal stages are described and illustrated herein, and compared with those of the related two species, $T$. sima H. MiLNE EDWARDS and $T$. danae STIMPSON.

The zoeae of the three species are very similar in general appearance, but they are distinguishable in the following characters. In the complete larval development, $T$. prymna may have four zoeal stages before reaching the megalopa stage, while in $T$. danae there are three zoeal stages, and $T$. sima has five (KURATA, 1975) or six (TERADA, 1979). The zoea of $T$. prymna has no chromatophore on the lateral surface of carapace which is present in that of $T$. sima. The first zoea of the Japanese T. prymna and T. sima is provided with ten setae on the basipod of maxilliped I, whereas that of the Australian $T$. danae has nine. The three closely related species are also distinguished from one another by bearing the different setations on the exopods of maxillipeds I and II.
\end{abstract}

\section{Introduction}

The complete zoeal development of the genus Thalamita, Portuninae Portunidae, has been studied in detail by Kurata (1975) and Terada (1979) on T. sima H. MiLne EDWARDS from Japan and by FIELDER and GREENWOOD (1979) on $T$. danae STIMPSON from Australia. The zoeal stages of $T$. prymna (HERBST) has not yet been completely 
studied. KURATA (1975) provided brief description of the first zoea of $T$. prymna without detailed illustrations of the appendages except for the structures of antenna II and telson.

T. prymna is widely distributed from Japan to Australia, and westwards through Red Sea to south Africa, from the low tide level to $20 \mathrm{~m}$ deep (SAKAI, 1976). The present paper deals with the complete zoeal development of $T$. prymna, which is successfully followed in the laboratory, and compared with those of the previously studied two species.

\section{Materials and Methods}

On 27 May 1982, an ovigerous female of Thalamita prymna was collected by means of a gill-net at the rocky bottom, depths from 5 to 10 meters, in the Sea of Enshunada, Shizuoka-ken. The ovigerous female was reserved in a plastic vessel $(70 \times 40 \times 30 \mathrm{~cm})$ with fresh seawater containing a bubbler until the larvae were hatched out, on 2 June 1982. As soon as the larvae hatched, about 300 individuals of zoeae were transferred into a small glass vessel $(10 \mathrm{~cm}$ in depth) filled with filtered fresh seawater about $7 \mathrm{~cm}$ deep. The water temperature at 11 a.m. was measured between 21.2 and $24.1^{\circ} \mathrm{C}$ during the experiment. The zoeae were fed on newly hatched nauplii of Artemia salina. The larvae were daily transferred to the new vessel with filtered fresh seawater, and some larvae and their exuviae were detected and preserved in 7 per cent formalin for examination. About eight examples and five exuviae of each zoeal stage were available for the study. Their appendages were dissected under a binocular dissecting microscope, and the fine structures of their appendages were observed under a microscope. The drawings of the materials and their appendages were made under the aid of a camera lucida.

\section{Results}

T. prymna may have four zoeal stages, because the cephalothoracic and abdomina' appendages in the fourth zoea show the conditions in the final zoeal stages of the related species. The minimal inter moult pereiod is five days for the stages I-II and II-III, and four days for the stages III-IV. The average length of carapace for each zoeal stage, as measured from the anterior end of the eye to the posterior edge of the carapace, is $0.48 \mathrm{~mm}, 0.54 \mathrm{~mm}, 0.82 \mathrm{~mm}$ and $1.24 \mathrm{~mm}$, respectively, and the average length between the tips of the rostral and the dorsal carapace spines is measured $1.02 \mathrm{~mm}, 1.14 \mathrm{~mm}, 2.00 \mathrm{~mm}$ and $2.60 \mathrm{~mm}$, for successive zoeal stages.

\section{Stable morphological characters throughout the zoeal stage}

Cephalothorax (Fig. 1, A) is spherial in shape, and provided with a rostral, a dorsal and a pair of short lateral spines. Rostral spine is smooth, directed downward, and 
slightly shorter than antenna II. Lateral spines are curved downward and about onefourth the length of the rostral one. Chromatophores (Fig. 1, A) are present on basipod of maxilliped I, and absent from basipod of maxilliped II, lateral and dorsal portions of carapace. There are a pair of mid-lateral projections on abdominal segments II and III (Fig. 1, H). The projections of segment II are larger, directed laterally, and those of segment III are rather small and directed posteriorly. Segments III, IV and V have posterolateral spines, those on segment III being longest. On the posterodorsal margin of abdominal segments II-V, there are a pair of submedian minute hairs. Antennal I (Fig. 1, B) is conical in shape, one-segmented, and provided with several aesthetes and setae. Antenna II (Fig. 1, A, C) is much longer than antenna I, and provided with an elongated spinous process bearing two rows of minute spinules on its distal half and with a smooth exopod bearing two unequal terminal setae. Exopod is much shorter than the spinous process, about one-sixth (in stages I and II) and about one-fourth (in stages III and IV) the length of spinous process. According to AIKAWA's criteria (1933), the antenna II of the present species seems to fall into the type $B_{4}$. Lamellar maxilla I (Fig. 1, D) is small, and consists of basal and coxal endites and a two-segmented endopod. Distal segment of endopod is three or four times as long as the proximal one. Setal formula of endopod is $4 \cdot 2-1$ (endopod with four apical and two inner lateral setae on distal segment, and one seta on the proximal segment). Maxilla II (Fig. 1, E) is also small, lamellate, and composed of an endopod, basal and coxal endites, and scaphognathite. Endopod is weakly bilobed, and its setation is 4.2 (four apical setae on the distal and two setae on the proximal lobe) $(5 \cdot 2$ setation rarely occurs in stage II). Maxilliped I (Fig. 1, F) is typical form for the genus, and the largest of all the cephalothoracic appendages. Endopod consists of five segments, the second and fourth of which are longer than the others. Unsegmented basipod possesses setation of $3 \cdot 3 \cdot 2 \cdot 2$ (three setae on the distal, three and two on the submedian, and two on the basal portion). Maxilliped II (Fig. 1, G) is very like maxilliped I at a glance, but the former differs from the latter in having short endopod with three-segments. Setation of endopod is $5-1-1$ (five terminal and subterminal setae on the distal, and one seta on each of the proximal two segments) and that of basipod is $1 \cdot 1 \cdot 1 \cdot 1$.

\section{The differentiation of appendages and abdominal segments during the zoeal development}

Antennae $I$ and $I I$ (Fig. 1, B, C)

The number of aesthetes and setae of the conical antenna I (Fig. 1, B) varies in the following manner; the stage I has $2 \cdot 1$ (two aesthetes and one seta), the stage II possesses $4 \cdot 4$, the stage III possesses $3 \cdot 2$, and the stage IV possesses $4 \cdot 4$. In the last zoea the bud of endopod of antenna I appears as a round little protuberance. The bud of endopod of antenna II (Fig. 1, C) also rudimentarily appears in the stage III. The 

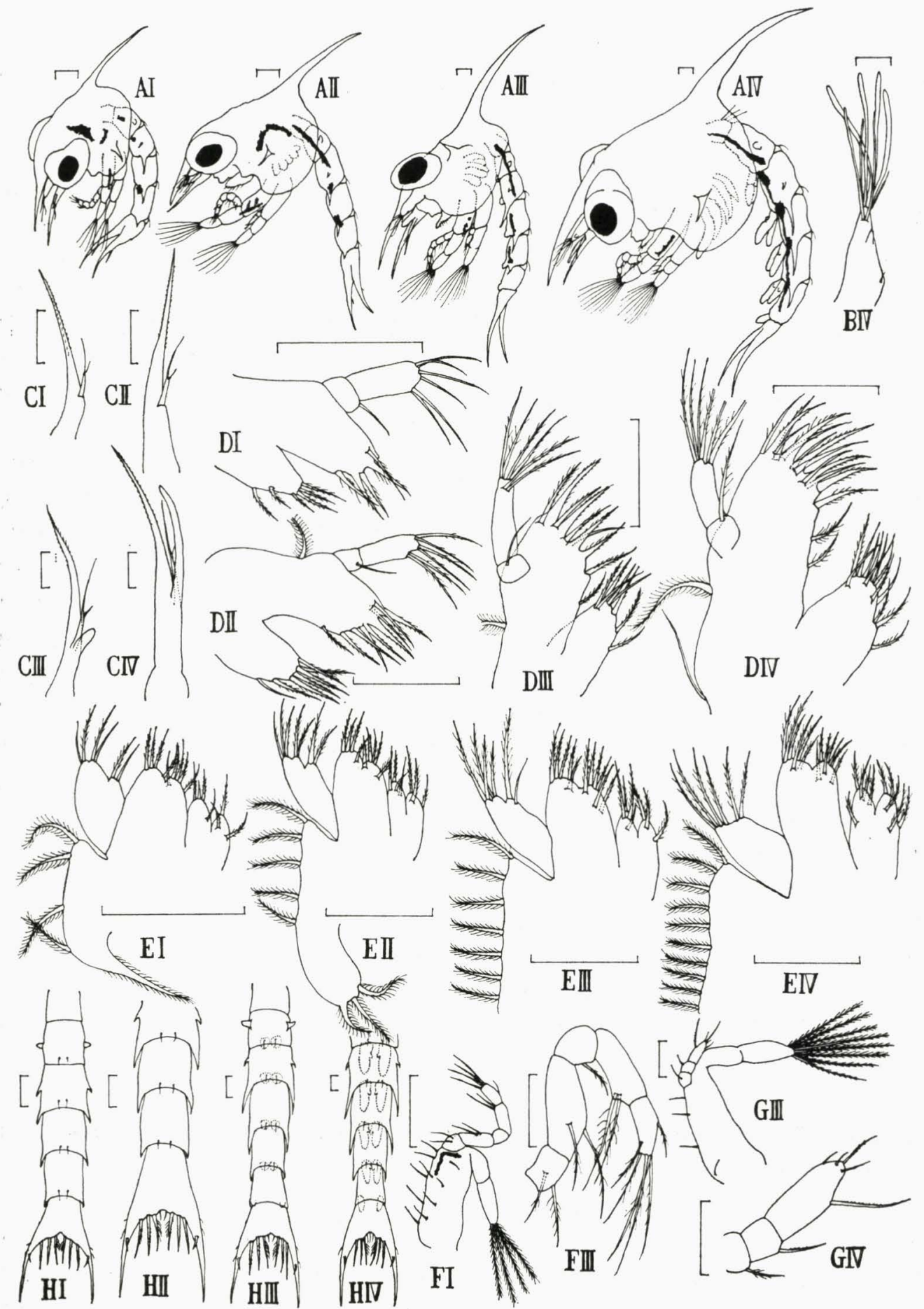

Fig. 1. Zoeal stages of Thalamita prymna (HERBST). A, lateral view of zoea; B, antenna I; C, antenna II; D, maxilla I; E, maxilla II; F, maxilliped I with its endopod; G, maxilliped II with its endopod; H, dorsal view of abdomen. Numerals associated with respective alphabets indicate the ordinal number of zoeal stages. Scales: $0.1 \mathrm{~mm}$. 
bud increases in size as development proceeds and it reaches to about two-thirds as long as spinous process in the last zoeal stage.

\section{Maxilla $I$ (Fig. 1, D)}

Basal endite of maxilla I bears five setae in stage I, nine in stage II, ten in stage III and sixteen or seventeen in stage IV. Coxal endite has six setae in stage I, seven in stage II, eight in stage III and twelve or thirteen in stage IV. In the second zoea, one large plumose seta appears on the outer edge of basal endite and the seta persists in the subsequent zoeal stages.

Maxilla II (Fig. 1, E)

Maxilla II has two endites, each of which is feebly bilobed, and furnished with several setae at the apex. Basal endite bears setation 4.5 (four setae on the outer lobe and five on the inner) in zoeal stages I and II, 5.6 in stage III and 6.7 in the last zoeal stage. Coxal endite bears the setation $4 \cdot 1: 2$ (four setae on the outer lobe, one apical and two lateral setae on the inner) in the first three stages, and $5 \cdot 2: 3$ in the last stage. In zoeal stage I, scaphognathite bears four plumose setae on the anterolateral margin and its posterior triangular extension terminates in a long plumose point (setation $4 \cdot 1$ ). In the following zoeal stages, the posterior triangular extension of scaphognathite is rounded at its tip. In stage II, the marginal plumose setae increase by three, of which two are situated on the round distal margin and one is added on the antero-lateral margin (setation 5.3). In the subsequent stages, the marginal plumose setae occur on the entire margin; the setae increase by eight to sixteen in stage III and by nine or ten to twenty-five or twenty-six in IV.

\section{Maxillipeds $I$ and $I I$ (Fig. 1, A, F, G)}

In maxilliped I (Fig. 1, F), endopodial setation is $4 \cdot 1-2-0-2-2$ (four apical and one outer marginal setae on segment V, two on segment IV, zero on segment III, and two on segments II and I) in zoeal stages I and II, but in stages III and IV an additional seta appears on each inner margin of the segments V and III, and its setation is 4.2 2-1-2-2. Exopod (Fig. 1, A) is composed of two segments with four long natatory apical setae in zoeal stage I, six in stage II, eight in stage III, and ten (rarely nine) in stage IV. In exopod of maxilliped II (Fig. 1, A), the number of natatory setae increases from four to six, eight and ten in the successive stages.

Abdomen (Fig. 1, A, H)

Abdomen (Fig. 1, A, H) consists of five segments and telson in the early two zoeal stages, and the sixth segment appears in the zoeal stage III. Each of postero-lateral corners of abdominal segments III to $\mathrm{V}$ is much produced towards the near and its apical portion sharply pointed, which is increased in size in advanced zoeal stages. Buds of pleopods and uropods appear in zoeal stage III on the ventraI surface of all posterior abdominal segments except for segment I, and their buds are becoming longer and biramous in the last stage. Buds of uropods are smaller than pleopods and not 
biramous in the last stage. Caudal furca of telson is long and straight. Each branch of the furca bears two hair-like lateral setae and one dorsal spine in the first three stages, and in the last stage each branch of the furca has only one lateral seta and one dorsal spine. According to TERADA's criteria (1980) the type of telson represents by $A_{1+2}$ in the stages I to III, and $A_{1+1}$ in the stage IV. Telson (Fig. $1, H$ ) is provided with three pairs of submedian setae, and also some additional short setae on medial margin in later zoeal stages, so that its setation varies in the following manner; $6+0$ in zoeal stage I, $6+2$ in stages II and III, and $6+3$ in stage IV.

Pereiopods (Fig. 1, A)

Five pairs of rudimentary pereiopods appear in zoeal stage II, these buds increase in length throughout the succeeding stages, but their segmentation is not discernible.

\section{Discussion}

A comparison of morphological features of the zoeal stages belonging to the genus Thalamita is restricted following three species, T. prymna (KURATA, 1975; the present paper), T. sima (TERAdA, 1979) and T. danae (FIELdER and GREenwood, 1979). The zoeae of $T$. prymna are very similar to those of $T$. sima and $T$. danae in the following charactees: 1) the rostral, dorsal and lateral carapace spines are present, 2) the antenna II is the type $\mathrm{B}_{4}, 3$ ) the setations of the endopods of the maxillae I and II, and the maxilliped II are $4 \cdot 2-1,4 \cdot 2$ and $5-1-1$, respectively, 4) the setation of the basipod of the maxilliped II is $1 \cdot 1 \cdot 1 \cdot 1,5$ ) the basal endite of the maxilla I has one long plumose seta on the outer margin in the later three zoeal stages, 6) the inner lobe of the coxal endite of the maxilla II has setation of $1: 2$ in the early stages, and 7) there are a pair of the mid-lateral projections on the abdominal segments II and III.

However, the zoeae of the three species can be distinguished from one another in the following points. T. danae has three zoeal stages (FIELdER and GreEnwood, 1979), T. prymna has four, and T. sima has six (TERADA, 1979) or five zoeal stages (KURATA, 1975). There is a chromatophore on the lateral surface of the carapace in all zoeal stages of $T$. sima, while the zoeae of $T$. prymna has no such chromatophore on the carapace. Unfortunately, in $T$. danae the description of the chromatophore pattern on the carapace is not given by FIELDER and GREENwood (1979). The first zoea of the two Japanese species, T. prymna and $T$. sima, have a total of ten setae (setation: $3 \cdot 3 \cdot 2 \cdot 2$ ) on the basipod of the maxilliped I, but the Australian $T$. danae has nine (setation: $2 \cdot 3 \cdot 2 \cdot 2$ ). In the two Japanese species, two pairs of the maxillipeds have four natatory setae in the first zoea, six in the second, eight in the third and ten in the fourth, whereas the zoeae of Australian $T$. danae has four in the first stage, eight in the second and twelve in the third stage. The abdominal segment VI of T. prymna and $T$. sima is added in stage III, whereas in $T$. danae the sixth abdominal segment appears in stage II. 


\section{Acknowledgement}

The author wishes to thank Professor Sigeo GAMô, Yokohama National University, for his kind help in preparing manuscript.

\section{References}

Aikawa, H., 1933. On larval forms of some Brachyura, Paper II; A note on indeterminable zoeas. Res. oceanogr. Works Jap., 5 : 124-254.

FieldeR, D. R. and J.G. GREenwood, 1979. Larval development of the swimming crab Thalamita danae Stimpson (Decapoda, Portunidae), reared in the laboratory. Proc. R. Soc. Qu., 90: 13-20.

Kurata, H., 1975. Larvae of Decapoda Brachyura of Arasaki, Sagami Bay-V. The swimming crabs of subfamily Portuninae. Bull. Nansei Reg. Fish. Res. Lab., 8: 39-65. (In Japanese with English Summary)

SAKAI, T., 1976. Crabs of Japan and the Adjacent seas. Kodansha Ltd. Tokyo.

Terada, M., 1979. A classification of zoea larvae in the subfamily Portuninae of the family

Portunidae. Zool. Mag., $88: 254-268$. (In Japanese with English Summary)
, 1980. Zoea larvae of four crabs in the subfamily Xanthinae. Zool. Mag., 89: 138-148. (In Japanese with English Summary)

ガザミ亜科 Portuninae に属するペニツヶガニ Thalamita prymna の抱卵個体を御前崎沿岸 の岩底に設置した刺網によって捕獲し, 実験室で飼育した。捊化したゾェア幼生にはアルテミ アのノープリウスを充分に給餪し，ゾェアIV期までを得ることができた。得られたゾェア各期 幼生につき, 全形と付属肢の形態を詳細に記載, 図示した。

本種ゾェアIV期の形態は今までに調べられた 種類のそれに酷似しているので, 間違いなくゾ エア終期であろう。本種ゾェア幼生をフタバベニッケガニ T. sima やミナミベニッケガニ T. danae と比較したところ, ゾェア期の数, 甲側縁部の色素胞, 顎脚 I の基節毛数, 両顎脚の外 肢遊泳毛数, 尾節の分節時期などに若干の違いが認められ, これらの部位により， 3 種幼生の 識別は可能である。 